\title{
Visual sensing of fluoride ions by dipyrrolyl derivatives bearing electron-withdrawing groups
}

\author{
TAMAL GHOSH and BHASKAR G MAIYA* \\ School of Chemistry, University of Hyderabad, Hyderabad 500 046, India \\ e-mail:bgmsc@uohyd.ernet.in
}

MS received 6 October 2003; revised 17 October 2003

\begin{abstract}
Two new, easy-to-prepare dipyrrolyl derivatives endowed with electron-withdrawing quinone or dicyano functionalities in their architecture permit the detection of fluoride ions under visual (naked-eye) as well as optical (absorption and fluorescence) and electrochemical conditions in organic solvents.
\end{abstract}

Keywords. Fluoride ion sensors; dipyrrolyl derivatives; binding constants.

\section{Introduction}

The coordination chemistry of anions is a relatively new area of research as opposed to that of cations. Indeed, sensing anions can, often, be quite challenging. ${ }^{1-5}$ Among the many inorganic anions, fluoride is drawing a special attention due to its beneficial (e.g. prevention of dental caries and treatment of osteoporosis) as well as detrimental (e.g. fluorosis) roles. $^{6-8}$ Recently, calix[4]pyrrole ${ }^{9,10}$ and dipyrrolylquinoxaline (DPQ) based receptors ${ }^{11-14}$ have been reported to be efficient sensors for $F^{-}$and other inorganic anions. Herein, we report two new dipyrrolyl receptors $\mathbf{1}$ and $\mathbf{2}$ (figure 1), both of which are avid binders of $F^{-}$. Structurally, while receptor $\mathbf{1}$ can be considered as a DPQ derivative having the quinone moiety as part of its extended $\pi$-framework, compound $\mathbf{2}$ is a newly introduced receptor motif, viz. dipyrrolylpyrazine (DPP), that is substituted with two cyano groups directly on its skeleton.

\section{Results and discussion}

Reaction of the easily synthesizable 1,2-di(1H-2pyrrolyl)-1,2-ethanedione ${ }^{11,16}$ with commercially available 1,2-diaminoanthraquinone or 1,2-diaminomaleonitrile readily furnished receptors $\mathbf{1}$ and $\mathbf{2}$ respectively, in $\sim 80 \%$ yield in each case. These new compounds were sufficiently characterized for their

*For correspondence purity and structural integrity by elemental analysis, FAB-MS, IR, UV/Vis and ${ }^{1} \mathrm{H}$ (1D and ${ }^{1} \mathrm{H}-{ }^{1} \mathrm{H}$ COSY) and ${ }^{13} \mathrm{C}$ NMR methods.

In the room temperature ${ }^{1} \mathrm{H}$ NMR spectra, while the two $\beta$-pyrrole protons of $1\left(2.56 \times 10^{-2} \mathrm{M}\right.$ in $\left.\left(\mathrm{CD}_{3}\right)_{2} \mathrm{SO}\right)$ resonated as two distinct signals at 6.52 and $6.65 \mathrm{ppm}$ (see figure 2 , trace $\mathrm{A}$ ), the corresponding protons of $2\left(3.84 \times 10^{-2} \mathrm{M}\right.$ in $\left.\mathrm{CDCl}_{3}\right)$ appeared at $7.37 \mathrm{ppm}$. We reasoned that close proximity of the symmetrically disposed and highly electron withdrawing cyano groups was responsible for the observed deshielding of the peak due to the $\beta$-pyrrole protons of 2 compared to the corresponding peaks of receptor 1. On the other hand, an 'unsymmetric' juxtaposition of the quinone subunit with respect to the DPQ framework seems to rationalize the dissimilar nature of the two pyrrole rings of $\mathbf{1}$.

During the NMR titration with $F^{-}$(tetrabutylammonium salt, $\left.[\mathrm{TBAF}]=0-12 \times 10^{-2} \mathrm{M}\right)$ both the

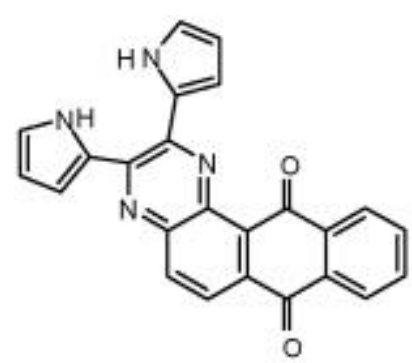

1

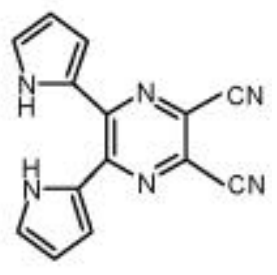

2
Figure 1. Molecular structures of receptors $\mathbf{1}$ and 2. 
$\beta$-pyrrole resonances of $\mathbf{1}$ initially merged and finally appeared as a broad band centred at $\sim 6.9 \mathrm{ppm}$ (see figure 2 , trace $\mathrm{B}$ ). The $\beta$-pyrrole resonance of $\mathbf{2}$ was also shifted during the titration with TBAF and was found to locate within a broad band centred at $7 \cdot 10 \mathrm{ppm}$ at the end of the titration. Similar broadening of the peaks as well as shifts in the resonance positions for the $\beta$-pyrrole protons have been noticed earlier in the ${ }^{1} \mathrm{H}$ NMR spectra of various DPQ derivatives in the presence of fluoride ion and were interpreted in terms of binding of $F^{-}$by the two pyrrolyl subunits. ${ }^{11-13}$ We believe that the same interpretation holds good for $\mathbf{1}$ and $\mathbf{2}$. Unambiguous evidence that $F^{-}$is involved in H-bonding interaction with the two pyrrole $-\mathrm{NH}$ protons comes from the fact that the resonances attributed to the $-\mathrm{NH}$ protons on 1 (11.87 and $11.16 \mathrm{ppm}$, figure 2) and 2 $(9.61 \mathrm{ppm})$ were initially broadened and finally disappeared from the spectrum upon successive addition of TBAF. Thus, the ${ }^{1} \mathrm{H}$ NMR data of $\mathbf{1}$ and $\mathbf{2}$ in the presence of $F^{-}$are consistent with a structural model which suggests that binding of $F^{-}$is facilitated by the rotation of the pyrrole rings of these receptors in such a way that the $-\mathrm{NH}$ protons direct

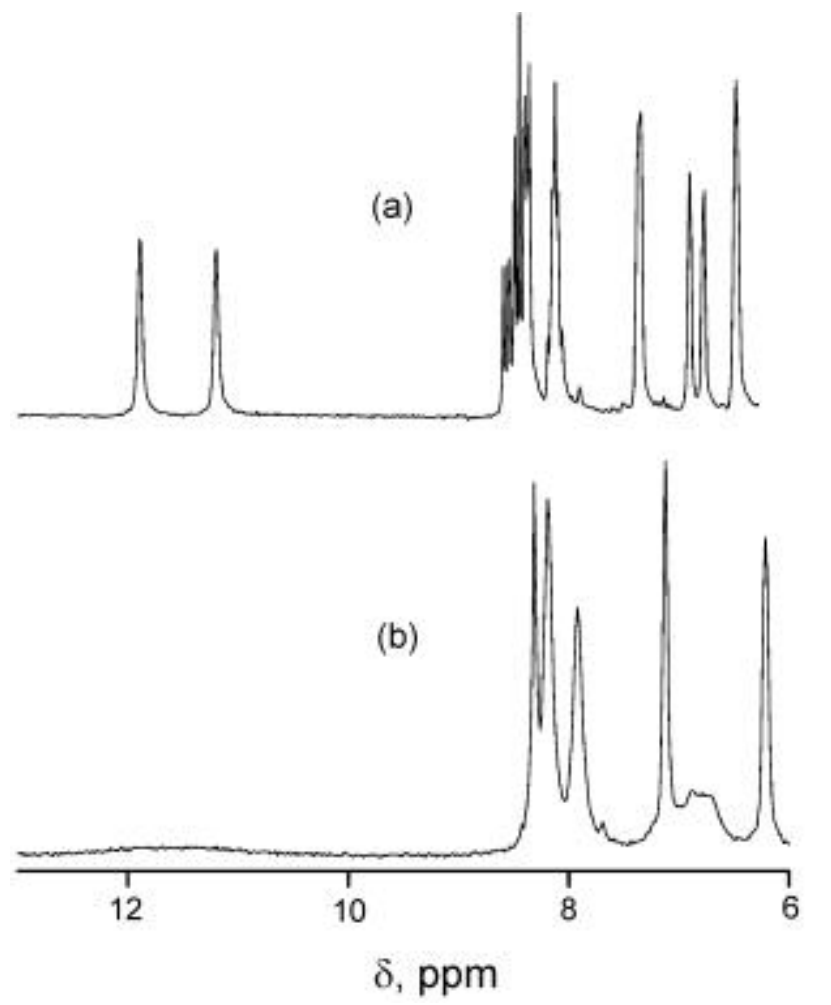

Figure 2. ${ }^{1} \mathrm{H}$ NMR spectra $\left(\left(\mathrm{CD}_{3}\right)_{2} \mathrm{SO}\right)$ of (a) receptor $\mathbf{1}$ $\left(2.56 \times 10^{-2} \mathrm{M}\right)$ and (b) a solution containing equimolar concentrations of 1 and TBAF $\left(2.56 \times 10^{-2} \mathrm{M}\right.$ each $)$. towards the lone pairs of the anion. ${ }^{11}$ Such a rotation is expected to aid the pyrrole rings to assume a "bite angle' suitable for the size of $F^{-}$and to position them atop the quinoxaline/pyrazine chromophores in such a way that orbital overlap between the pyrrole and quinoxaline/pyrazine subunits are perturbed and the optical and electrochemical properties of these chromophores are altered. As will be discussed below, this is indeed the case.

In the naked-eye colorimetric experiments, receptors 1 and $2\left(1 \times 10^{-4} \mathrm{M}\right.$ in $\mathrm{CH}_{2} \mathrm{Cl}_{2}$ or DMSO $)$ showed dramatic colour changes from red to green and from yellow to orange-red, respectively, in the presence of TBAF $\left(3 \times 10^{-3} \mathrm{M}\right)$, figure 3 . Both the receptors were found to be insensitive to the addition of $\mathrm{Cl}^{-}, \mathrm{Br}^{-}, \mathrm{I}^{-}$or $\mathrm{ClO}_{4}^{-}$(up to $\sim 1000$ mole equivalents excess; see figure 3 ). Interestingly, the addition of $F^{-}\left(3 \times 10^{-3} \mathrm{M}\right)$ to those solutions of $\mathbf{1 / 2}$ $\left(1 \times 10^{-4} \mathrm{M}\right)$ containing excess of these latter anions also generated the expected green/orange-red colour suggesting that these receptors are selective binders of $F^{-}$.

During the titrations with $F^{-}$in $\mathrm{CH}_{2} \mathrm{Cl}_{2}$, the $\mathrm{UV} / \mathrm{Vis}$ bands seen at $508 \mathrm{~nm}$ for 1 (figure 4) and

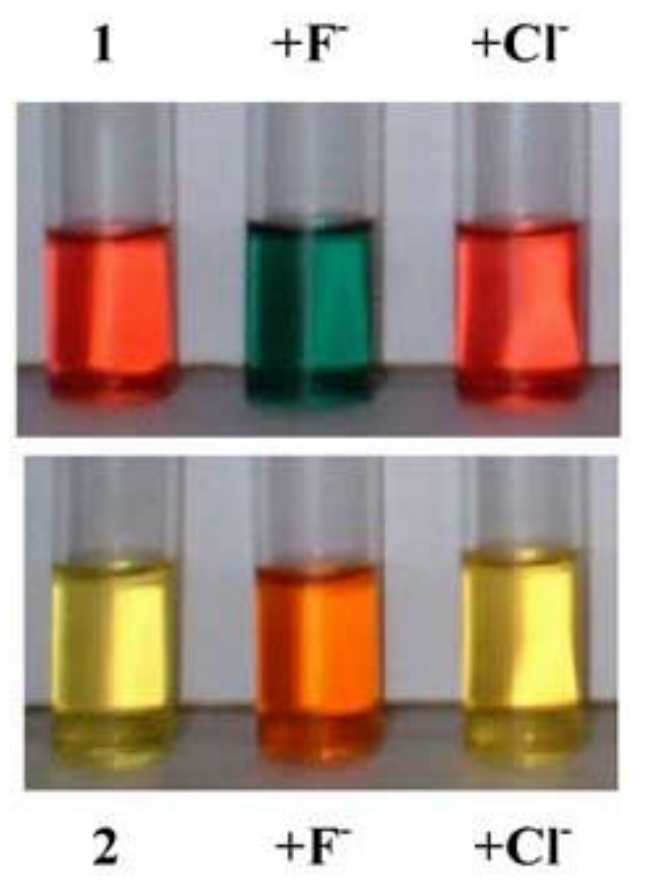

Figure 3. Colour changes observed for $\mathbf{1}$ and $\mathbf{2}$ in $\mathrm{CH}_{2} \mathrm{Cl}_{2}$ upon the addition of anions as tetrabutylammonium salts. Similar colour changes were also noticed when DMSO was used as the solvent. Concentrations employed: $[1] /[2]=1 \times 10^{-4} \mathrm{M} ; \quad\left[F^{-}\right]=3 \times 10^{-3} \mathrm{M}$ and $\left[\mathrm{Cl}^{-}\right]=$ $9 \times 10^{-2} \mathrm{M}$. 


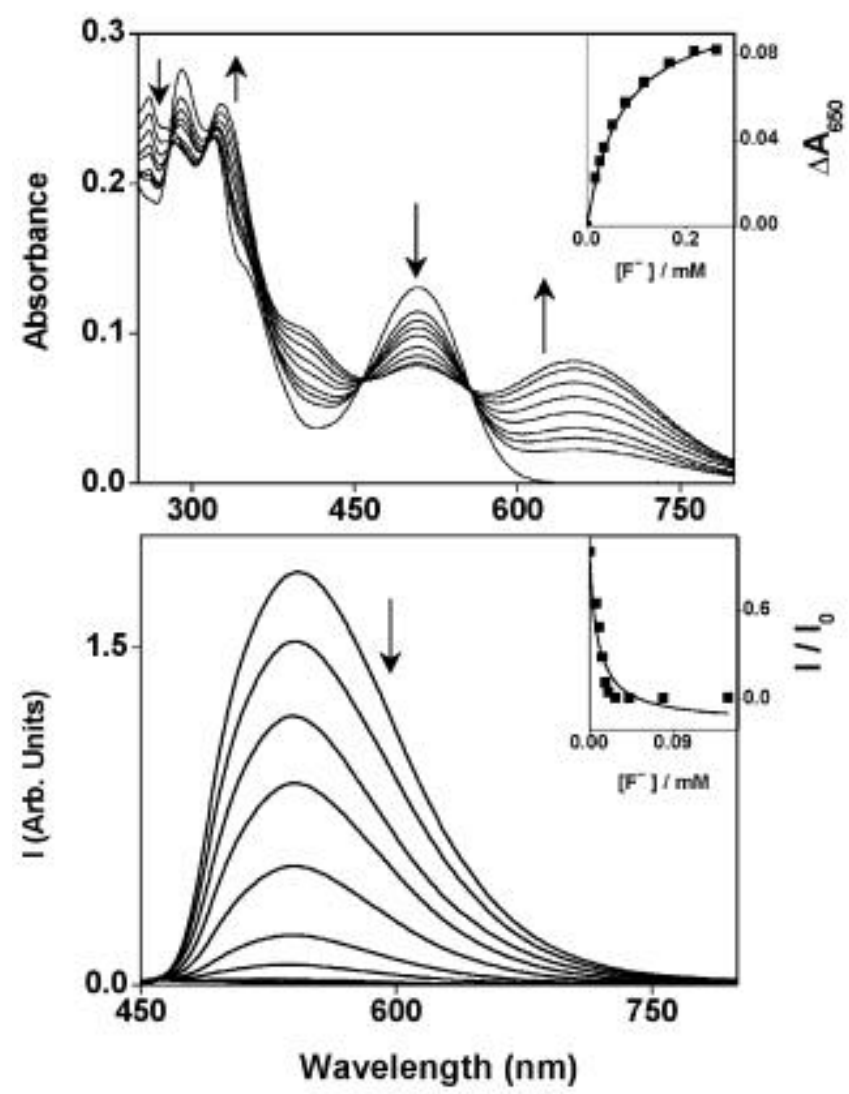

Figure 4. Top panel: UV/Vis spectral changes seen for $1.0 \times 10^{-5} \mathrm{M} 1$ upon the addition of successive amounts of TBAF $\left(0-3 \times 10^{-4} \mathrm{M}\right)$ in $\mathrm{CH}_{2} \mathrm{Cl}_{2}$. Bottom panel: Fluorescence spectral changes seen for $2\left(\lambda_{\mathrm{exc}}=430 \mathrm{~nm}\right.$; $\mathrm{OD}=0.18)$ upon the addition of $\operatorname{TBAF}\left(0-3 \times 10^{-4} \mathrm{M}\right)$ in $\mathrm{CH}_{2} \mathrm{Cl}_{2}$. The inset in each case shows fit of the experimental data to a $1: 1$ binding profile. $^{17}$

$427 \mathrm{~nm}$ for 2 disappeared with a concomitant appearance of new bands at 652 and $469 \mathrm{~nm}$, respectively. Upon the addition a drop of water, the original band and the solution colour reappeared in each case. Thus, the complexation between $F^{-}$and $\mathbf{1 / 2}$ is reversible in nature. The binding constants $\left(K_{a}\right)$ obtained by UV/Vis titration experiments are $1.62 \times$ $10^{4}$ and $1.65 \times 10^{5} \mathrm{M}^{-1}( \pm 10 \%)$ for $\mathbf{1}$ and 2 respectively. ${ }^{17}$ The fact that $K_{a}$ for $\mathbf{2}$ is an order of magnitude higher probably indicates the greater electron deficiency and enhanced hydrogen bond-donating character of this receptor. It should be noted here that addition of $\mathrm{Cl}^{-}, \mathrm{Br}^{-}, \mathrm{I}^{-}$or $\mathrm{ClO}_{4}^{-}$to solutions containing $\mathbf{1}$ or $\mathbf{2}$ produced only marginal spectral changes; the $K_{a}$ values, being too low, could not be estimated by this method in these cases.

Both the new receptors were found to show fluorescence $\left(\mathrm{CH}_{2} \mathrm{Cl}_{2}, \lambda_{\mathrm{em}}, \mathrm{nm}\left(\varphi_{f}\right): \mathbf{1}, 693(0.015) ; 2,541\right.$
$(0 \cdot 41)$ ), the intensity of which decreased upon binding with $F^{-}$in each case. Fluorescence titration experiments followed by standard curve fitting ${ }^{17}$ and Job-plot analyses not only provided the $K_{a}$ values (1: $1.32 \times 10^{4} \mathrm{M}^{-1}$ and 2: $1.38 \times 10^{5} \mathrm{M}^{-1}$ ), which were comparable to those obtained in the UV/Vis experiments, but also suggested that the binding stoichiometery in each case is 1:1 (see figure 4). Quenching of fluorescence was also observed for $\mathbf{1}$ and 2 in the presence of $\mathrm{Cl}^{-}, \mathrm{Br}^{-}, \mathrm{I}^{-}$or $\mathrm{ClO}_{4}^{-}$, albeit, only upon the addition of large excess $\left(>10^{-3} \mathrm{M}^{-1}\right)$ of these ions. Rough estimation of the binding constants gave values that vary between ca. $40-500 \mathrm{M}^{-1}$ for these anions.

Cyclic- and differential pulse (DPV) voltammetric studies revealed that $\mathbf{1}\left(5 \times 10^{-4} \mathrm{M}\right)$ and $\mathbf{2}(1 \times$ $10^{-3} \mathrm{M}$ ) undergo quasi-reversible reductions at -0.63 and $-1.12 \mathrm{~V}$ respectively, in $\mathrm{CH}_{2} \mathrm{Cl}_{2}, 0.1 \mathrm{M}$ TBAP. Anodic shifts of the DPV peaks were noticed upon successive addition of TBAF to these solutions, with the shifts in the presence of equimolar concentration of $\left[\mathrm{F}^{-}\right]$being 190 and $220 \mathrm{mV}$ for $\mathbf{1}$ and 2 respectively. The larger anodic shift observed for receptor 2 in the presence of $F^{-}$is consistent with the higher $K_{a}$ value obtained by the UV/Vis and fluorescence titration methods described above.

\section{Conclusion}

In conclusion, the new dipyrrolyl derivatives $\mathbf{1}$ and 2 are easy-to-prepare fluoride ion receptors and allow the detection of $F^{-}$under visual as well as optical and electrochemical conditions in organic solvents. Currently, we are engaged in the design and anion-sensing studies of more such dipyrrolyl derivatives endowed with electron-withdrawing substituents.

\section{Acknowledgement}

We thank the Council of Scientific and Industrial Research, New Delhi and Board of Research in Nuclear Sciences, Mumbai for financial support of this work. We also thank the UPE Programme of the University Grants Commission, New Delhi for some of the instrumentation facilities.

\section{${ }^{\dagger}$ Selected data for $\mathbf{1}$ and $\mathbf{2}$}

1: Analysis: Calcd. For $\mathrm{C}_{24} \mathrm{H}_{14} \mathrm{~N}_{4} \mathrm{O}_{2}$ : C, 73.84; H, 3.61; $\mathrm{N}, 14.35 \%$. Found: C, 73.83; H, 3.71; N, 14.13. FAB-MS $(\mathrm{m} / \mathrm{z}): 392(\mathrm{M}+2 \mathrm{H})^{+} ; \quad$ m.p.: $\quad>250^{\circ} \mathrm{C}$. 
UV/Vis $\left(\mathrm{CH}_{2} \mathrm{Cl}_{2}\right) \quad \lambda_{\max } / \mathrm{nm}(\log \varepsilon): 290$ (4.43), 508 (4.09); IR (KBr, $\left.\mathrm{cm}^{-1}\right): 3376,1663,1657 .{ }^{1} \mathrm{H}$ NMR $\left(200 \mathrm{MHz},\left(\mathrm{CD}_{3}\right)_{2} \mathrm{SO}\right) \delta=6.22(2 \mathrm{H}, m), 6.52(1 \mathrm{H}$, $m), 6.65(1 \mathrm{H}, m), 7.13(2 \mathrm{H}, m), 7.94(2 \mathrm{H}, m), 8.20$ $(2 \mathrm{H}, m), 8.25\left(1 \mathrm{H}, d,{ }^{3} J_{\mathrm{H}-\mathrm{H}}=10 \mathrm{~Hz}\right), 8.40(1 \mathrm{H}, d$, $\left.{ }^{3} J_{\mathrm{H}-\mathrm{H}}=10 \mathrm{~Hz}\right), 11 \cdot 16(1 \mathrm{H}, b r s), 11.87(1 \mathrm{H}, b r s)$; ${ }^{13} \mathrm{C}$ NMR $\left(50 \mathrm{MHz}\right.$, DMSO $\left.d_{6}\right) \delta 114.7,114.9$, $118 \cdot 4,119 \cdot 1, \quad 128 \cdot 3,128 \cdot 8, \quad 130 \cdot 5,131 \cdot 4,131 \cdot 7$, $133 \cdot 3,133 \cdot 9,137 \cdot 1,138 \cdot 7,138 \cdot 9,147 \cdot 3$.

2: Analysis: Calcd. For $\mathrm{C}_{14} \mathrm{H}_{8} \mathrm{~N}_{6}$ : C, 64.61; H, 3.10; N, 32.30. Found: C, 65.11; H, 2.99; N, 33.12. FABMS (m/z), 260; m.p.: $185 \pm 1^{\circ} \mathrm{C}$. UV/Vis $\left(\mathrm{CH}_{2} \mathrm{Cl}_{2}\right)$ $\lambda_{\max } / \mathrm{nm}(\log \varepsilon): 338$ (4.27), 427 (4.28); IR (KBr, $\left.\mathrm{cm}^{-1}\right): 3314,2243 .{ }^{1} \mathrm{H}$ NMR $\left(200 \mathrm{MHz}, \mathrm{CDCl}_{3}\right)$ $\delta=6.33(2 \mathrm{H}, m), 7.12(2 \mathrm{H}, m), 7.37(2 \mathrm{H}, m), 9.61$ $(2 \mathrm{H}, b r s) ;{ }^{13} \mathrm{C}$ NMR $\left(50 \mathrm{MHz}, \mathrm{CDCl}_{3} / \mathrm{CD}_{3} \mathrm{OD}, 4: 1\right.$, $v / v): \quad 112 \cdot 0, \quad 115 \cdot 4, \quad 116 \cdot 9, \quad 126 \cdot 6, \quad 126 \cdot 9, \quad 127 \cdot 9$, $145 \cdot 4$.

\section{References}

1. Dietrich B and Hosseini M W 1997 In Supramolecular chemistry of anions (eds) A Bianchi, K BowmanJames and E Garcí a-España (New York: WileyVCH) pp. 45-62

2. Beer P D and Gale P A 2001 Angew. Chem., Int. Ed. 40486

3. Gale P A 2001 Coord. Chem. Rev. 21379

4. Sessler J L, Camiolo S and Gale P A 2003 Coord. Chem. Rev. 24017
5. Aldakov D and Anzenbacher Jr P 2003 Chem. Commun. 1394, and refs therein

6. Kleerekoper M 1998 Endocrinol. Metab. Clin. North Am. 27441

7. Kirk K L 1991 Biochemistry of the halogens and inorganic halides (New York: Plenum) p. 58

8. Wiseman A 1970 Handbook of experimental pharmacology (Berlin: Springer-Verlag) vol. 20, part 2, pp. 48-97

9. Nielsen K A, Jeppesen $\mathbf{J} \mathrm{O}$, Levillain $\mathrm{E}$ and Becher $\mathbf{J}$ 2003 Angew. Chem., Int. Ed. 42187

10. Miyaji H, Sato W and Sessler J L 2000 Angew. Chem., Int. Ed. 391777

11. Black C B, Andrioletti B, Try A C, Ruiperez C and Sessler J L 1999 J. Am. Chem. Soc. 12110438

12. Anzenbacher Jr P, Try A C, Miyaji H, Jursikova K, Lynch V M, Marquez M and Sessler J L $2000 \mathrm{~J}$. Am. Chem. Soc. 12210268

13. Mizuno T, Wei W-H, Eller L R and Sessler J L 2002 J. Am. Chem. Soc. 1241134

14. Anzenbacher Jr P, Tyson D S, Jursikova K and Castellano F N 2002 J. Am. Chem. Soc. 1246232

15. It should be noted here that, while this manuscript was being prepared, synthesis and characterization of sensor 2 and a few of its derivatives have been reported by Sessler et al (Sessler J L, Pantos G D, Katayev E and Lynch V M 2003 Org. Lett. 5 4141) (ASAP articles, October 01 release). However, fluoride ion sensing abilities of $\mathbf{2}$ or of its derivatives have not been presented in that paper

16. Behr D, Brandange S and Lindstrom B 1973 Acta Chim. Scand. 272411

17. Connors K A 1987 Binding constants: The measurement of molecular complex stability (New York: Wiley-VCH) 